\title{
PENERAPAN AZAS KEKELUARGAAN DAN KEADILAN \\ PADA PENYELESAIAN KREDIT BERMASALAH PADA PEMBIYAAN PERUMAHAN DI INDONESIA
}

\author{
IMPLEMENTATION OF FAMILY AND JUSTICE PRINCIPLES \\ IN CREDIT SETTLEMENT PROBLEM IN INDONESIA HOUSING FINANCE
}

\author{
Rosyidi Hamzah \\ Universitas Islam Riau \\ rosyidihamzah@law.uir.ac.id
}

\begin{abstract}
The house is a basic need for everyone. To assess the suitability of life of a community one indicator is the house. With a credit system for purchasing a house, most Indonesians can own a house. When the community was unable to pay home loan installments, the house will be scribbled by banks like this house in a bank escort. By drafting the debtor's house for not being able to pay housing loans, provides social and psychological sanctions to the debtor. Losses due to social and psychological sanctions for the debtor are more severe compared to sanctions that are material. This practice is not in accordance with the principle of kinship and the principle of justice which is an inseparable part of the Pancasila economic system.
\end{abstract}

Keyword : Housing Finance, Family and Justice Principle

\begin{abstract}
ABSTRAK
Rumah adalah kebutuhan dasar bagi setiap orang.Untuk menilai layak atau tidaknya kehidupan dari suatu masyarakat salah satu indikatornya adalah rumah. Dengan sistim kredit dalam pembelian sebuah rumah maka sebagian besar masyarakat Indonesia bisa memiliki rumah. Pada saat masyarakat tadi tidak mampu membayar angsuran kredit rumah maka rumah tersebut akan dicoret-coret oleh pihak bank seperti rumah ini dalam pengawai bank. Dengan di coret-coretnya rumah debitur karena tidak mampu membayar kredit perumahan, memberikan sanksi sosial dan psikologis kepada debitur. Kerugian akibat dari sanksi sosial dan psikologis bagi debitur ini lebih berat dibandingkan dengan sanksi yang bersifat materiil. Praktek ini tidak sesuai dengan azas kekeluargaan dan prinsip keadilan yang merupakan bagian dari tidak terpisahkan dari sistim ekonomi Pancasila.
\end{abstract}

Kata Kunci: Pembiayan Rumah, Prinsip Kekeluargaan dan Keadilan

\section{PENDAHULUAN}

Rumah merupakan kebutuhan pokok bagi kehidupan. Rumah sebagai tempat berteduh, istirahat, dan tempat domisili seseorang. Rumah adalah kebutuhan dasar bagi setiap orang.Untuk menilai layak atau tidaknya kehidupan dari suatu masyarakat salah satu indikatornya adalah rumah. Dari rumah pula sebuah keluarga dijadikan tempat untuk mengatur dan merencanakan kehidupan selanjutnya. Pada sisi yang lain rumah juga merupakan sebuah bentuk cara 
berinteraksi dengan masyarakat lainnya (Muhtar, 2017).

Dalam stratifikasi sosial rumah merupakan identitas sosial seseorang. Dari bentuk arsitektur dan interiornya bisa terlihat seperti apa pola hidup pemilik rumah, status sosialnya serta cara bermasyarakatnya. Begitu pentingnya sebuah rumah bagi kehidupan seseorang, banyak orang membeli rumah dengan berbagai cara, baik dibayar secara tunai atau kredit. Untuk membangun rumah yang layak huni bagi masyarakat membutuhkan biaya yang cukup besar oleh karena itu sebagian masyarakat Indonesia yang masih berada dibawah garis kemiskinan, banyak membeli rumah dengan cara kredit (Rusmawati, 2015).

Dengan sistim kredit dalam pembelian sebuah rumah maka sebagian besar masyarakat Indonesia bisa memiliki rumah. Dimana dengan sistim kredit cukup dengan membayar uang muka yang tidak terlalu besar maka seseorang bisa memiliki sebuah rumah dengan syarat tetap harus membayar cicilan dalam jangka tertentu sebagaimana yang diperjanjikan didalam akad perjanjian kredit (Purwanto, 2016).

Salah satu lembaga yang paling banyak memberikan kredit dibidang perumahan adalah lembaga perbankan, malahan ada sebuah bank yang fokus terhadap kredit perumahan seperti Bank Tabungan Negara (BTN). Didalam dunia perbankan sebelum memberikan kredit kepada calon debitur maka diwajibkan untuk membuat sebuah perhitungan yang mendalam apakah calon debitur ini layak atau tidak untuk mendapatkan fasilitas kredit tersebut, ini merupakan amanat dari UndangUndang Nomor 10 Tahun 1998 tentang Perbakan Pasal 8 Ayat (1) yang berbunyi Bank wajib mempunyai keyakinan berdasarkan analisis yang mendalam atas itikad baik dan kemampuan serta kesanggupan nasabah debitur untuk melunasi utangnya sesuai dengan yang diperjanjikan.

Didalam prakteknya dalam melakukan analisis yang mendalam terhadap calon debitur dilakukan dengan melihat terhadapwatak calon debitur, kemampuan untuk membayar utang, posisi modal, agunan dan prospek usaha calon debitur. Apabila calon debitur telah mendapatkan fasilitas kredit berarti debitur tersebut telah lulus dalam penilaian yang dilakukan oleh kreditur dalam hal ini bank. Maka untuk memberikan kepastian hukum dalam perjanjian kredit tersebut dibuatlah Perjanjian Kredit secara tertulis antara debitur dan kreditur.

Di dalam Perjanjian Kredit tersebut tertuang semua kewajiban antara debitur dan kreditur. Salah satu klausul didalam perjanjian tersebut adalah klausul tentang adanya wan prestasi (ingkar janji) yang dilakukan debitur seperti debitur tidak lagi membayar angsuran kredit sebagaimana yang telah diperjanjikan. Maka berdasarkan perjanjian kredit tersebut rumah tersebut dilelang kemudian hasil penjualan lelang separuhnya dibagikan kepada debitur dan separuhnya lagi dikembalikan kepada kreditur berdasarkan jumlah hutang dan piutang, hal ini telah diamanatkan oleh UndangUndang Nomor 4 Tahun 1996 tentang Hak Tanggungan.

Rahmawan et al., (2017) dalam penelitiannya menemukan bahwa dalam prakteknya apabila debitur wan prestasi maka rumah debitur akan dicoret-coret oleh pihak bank seperti rumah ini dalam pengawan bank " $\mathrm{X}$ ".Secara tidak lansung ini merugikan debitur secara sosial. Para tetangga akan melihat dan menimbulkan citra negative bagi 
debitur dan keluarga debitur. Bagaimana jika debitur memiliki anak dan anaknya memiliki teman-teman, tentu anak tersebut mendapatkan dampak psikologis dihadapan temantemannya jika diketahui oleh temantemannya. Sudahlah debitur mendapat kerugian materi janganlah dibebankan juga debitur menderita kerugian sosial dan psikologis.

Di tengah kondisi yang kian sulit terkadang kita tidak bisa memprediksi perekonomian, terkadang naik dan terkadang turun. Jikalau debitur wan prestasi maka silahkan lansung lelang saja rumah tersebut tanpa mencoret-mencoret rumah. Padahal coret-mencoret rumah tidak diatur dalam peraturan perundangundangan (Suarjaya et al., 2017).

Didalam Pasal 33 UUD 1945 jelas menyatakan bahwa perekonomian disusun atas azas bersama dan kekeluargaan.Yang namanya keluarga memiliki ikatan batin yang kuat, saling melindungi, saling membantu dan saling menutupi aib masing-masing anggota keluarganya. Praktek coret mencoret apabila debitur tidak mampu membayar angsuran kredit bukanlah bagian dari azas kekeluargaan. Budaya timur memiliki nilai saling hargamenghargai dan hormat-menghormati satu sama lain, berbeda dengan budaya barat yang jauh dari nilai kekeluargaan seperti individualis dan liberalis.

\section{METODE PENELITIAN}

Metode Penelitian yang digunakan adalah metode penelitian hukum normatif. Data yang digunakan adalah data sekunder yang terdiri dari bahan hukum primer berupa peraturan perundang-undangan yang terkait pembahasan seperti Undang-Undang Dasar 1945, TAP MPR RI Nomor VI/MPR/2001 tentang Etika Kehidupan Berbangsa, Undang-Undang Nomor 10
Tahun 1998 tentang Perbankan, Undang-Undang Nomor 4 Tahun 1996 tentang Hak Tanggungan, UndangUndang Nomor 1 Tahun 2011 tentang Perumahan dan peraturan perundangundangan terkait lainnya. Adapun bahan hukum sekunder terdiri dari jurnaljurnal, buku-buku dan pendapat para ahli yang berkenaan dengan moralitas, kredit dan perumahan.

\section{HASIL DAN PEMBAHASAN}

Undang-Undang Dasar Negara Republik Indonesia Tahun 1945, Pasal $28 \mathrm{H}$ ayat (1) menyebutkan, bahwa setiap orang berhak hidup sejahtera lahir dan batin, bertempat tinggal, dan mendapatkan lingkungan hidup yang baik dan sehat. Rumah mempunyai peranan yang sangat strategis dalam pembentukan watak serta kepribadian bangsa sebagai salah satu upaya membangun manusia Indonesia seutuhnya, berjati diri, mandiri, dan produktif sehingga terpenuhinya kebutuhan tempat tinggal merupakan kebutuhan dasar bagi setiap manusia, yang akan terus ada dan berkembang sesuai dengan tahapan dan siklus kehidupan manusia.

Negara bertanggung jawab melindungi segenap bangsa Indonesia melalui penyelenggaraan perumahan dan kawasan permukiman agar masyarakat mampu bertempat tinggal serta menghuni rumah yang layak dan terjangkau didalam lingkungan yang sehat, aman, harmonis dan berkelanjutan di seluruh wilayah Indonesia. Sebagai salah satu kebutuhan dasar manusia, idealnya rumah harus dimiliki oleh setiap keluarga, terutama bagi masyarakat yang berpenghasilan rendah dan bagi masyarakat yang tinggal didaerah padat penduduk diperkotaan. Negara juga bertanggung jawab dalam menyediakan dan memberikan kemudahan perolehan 
rumah bagi masyarakat melalui penyelenggaraan perumahan dan kawasan permukiman serta keswadayaan masyarakat. Penyediaan dan kemudahan perolehan rumah tersebut merupakan satu kesatuan fungsional dalam wujud tata ruang, kehidupan ekonomi, dan sosial budaya yang mampu menjamin kelestarian lingkungan hidup sejalan dengan semangat demokrasi, otonomi daerah dan keterbukaan dalam tatanan kehidupan bermasyarakat, berbangsa dan bernegara (Ellsya \& Kashadi, 2016). Pancasila sebagai dasar filsafat negara Indonesia secara yuridis tercantum dalam pembukaan UndangUndang 1945, alinea IV, yang berkedudukan sebagai tertib hukum tertinggi dalam peraturan perundangundangan negara Republik Indonesia. Oleh karena itu, merupakan suatu sumber hukum dasar beserta hukum positif lainnya. Oleh karena itu Pancasila disebut sebagai staatsfundamentalnorm atau norma dasar bagi derivasi peraturan hukum positif lainnya di negara kesatuan Republik Indonesia. Konsekuensinya secara yuridis Pancasila terletak pada kelansungan hidup negara Republik Indonesia, serta dalam hubungan dengan hukum positif Indonesia sebagai sumber tolak ukur serta arah bagi hukum positif Indonesia.

Konsekuensi Pancasila sebagai staatsfundamentalnorm, nilai-nilai yang terkandung didalam sila-sila Pancasila harus membumi dan terealisasi bukan hanya didalam aturan-aturan hukum, namun juga didalam segala aktifitas yang ada ditengah-tengah masyarakat.Salah satu sila didalam Pancasila yakni keadilan sosial bagi seluruh rakyat Indonesia.Sila ini memiliki nilai yang mendalam bagaimana menciptakan keadilan dalam setiap segi kehidupan masyarakat, salah satunya menciptakan keadilan dibidang penyelesaian sengketa kredit perumahan.

Secara yuridis penyelesaian sengketa perkreditan rumah yang dijaminkan dengan hak tanggungan diatur didalam Undang-Undang Nomor 4 Tahun 1996 tentang Hak Tanggungan.Didalam Pasal 6 disebutkan apabila debitur cidera janji maka jalan yang ditempuh adalah dengan cara menjual lansung rumah tersebut dipelelangan umum.Kemudia didalam Pasal 20 juga diberikan alternatif lainnya seperti bisa dijual di luar pelelangan umum dengan syarat adanya kesepakatan antara debitur dan kreditur untuk memperoleh harga yang tertinggi.Jalan yang terakhir ini lebih baik ditempuh dari pada yang pertama karena didalam penyelesaiannya mempriorotaskan keuntungan bagi kedua belah pihak.

Dalam penyelesaian kredit macet dibidang perumahan di negara Indonesia masih massif menggunakan cara-cara yang tidak sesuai dengan nilai-nilai Filosopi Pancasila yakni sila kelima keadilan sosial bagi seluruh rakyat Indonesia. Dengan di coretcoretnya rumah oleh pihak perbankan pada saat debitur cidera janji dalam melakukan pembayaran angsuran kredit, maka secara lansung bank memberikan sanksi secara sosial dan psikologis terhadap debitur. Padahal perjanjian kredit pembiayaan rumah adalah perjanjian kontraktual yang bersifat keperdataan, jika dalam pelaksanaan perjanjian mengalami cidera janji maka penyelesaiannya pun juga harus bersifat keperdataan.

Sifat keperdataan dari penyelesaian kredit perumahan yang bermasalah ini dilaksanakan dengan menjual rumah tersebut baik melalui pelelangan umum maupun di bawah tangan berdasarkan kesepakatan kedua belah pihak, hasil dari penjualan rumah 
tersebut dibayarkan untuk membayar sisa hutang dan apabila bersisa dikembalikan kepada debitur. Dari sifat keperdataan ini terlihatlah kedudukan yang seimbang antara hak dan kewajiban debitur dan kreditur.Sehingga tercerminlah filosopi keadilan seperti yang diamanatkan oleh Pancasila.Hanya dengan keadilan, peradaban bangsa kita dapat berkembang.

Dengan di coret-coretnya rumah debitur karena tidak mampu membayar kredit perumahan, memberikan sanksi sosial dan psikologis kepada debitur. Kerugian akibat dari sanksi sosial dan psikologis bagi debitur ini lebih berat dibandingkan dengan sanksi yang bersifat materiil. Sanksi sosial ini melahirkan stigma negatif di tengah masyarakat terhadap debitur sehingga akan menyulitkan debitur untuk melakukan kegiatan bisnis dikemudian hari, sebab dunia bisnis adalah dunia kepercayaan dan nama baik.Nama baik merupakan asset yang sangat berharga dalam dunia bisnis.Dampak Psikologis bukan hanya dirasakan oleh debitur termasuk juga anggota keluarga debitur yang tinggal dirumah tersebut.

Didalam

Alternatif

Penyelesaian Sengketa (APS) memiliki semangat untuk menyelesaikan sengketa bersifat tertutup untuk umum (close door session) serta kerahasiaan para pihak terjamin (confidentiality). Sehingga permasalahan hanya diketahui oleh para pihak saja. Namun ini bertolak belakang dengan proses coret mencoret rumah ketika debitur wanprestasi dalam membayar kredit rumah, seolah-olah kreditur mengumumkan kepada halayak ramai jika debitur telah melakukan wanprestasi.

Proses coret mencoret rumah dalam penyelesaian kredit bermalasah sangat jauh dari nilai-nilai keadilan sosial. Perekonomian disusun bukanlah secara individualistis namun disusun untuk mewujudkan keadilan dan kesejahteraan yang merata bagi semua rakyat Indonesia. Keadilan dalam hubungan ekonomi adalah senantiasa memberikan kepada sesama apa yang semestinya diterima sebagai haknya dan senantiasa membagi segala kenikmatan dan beban secara merata sesuai dengan sifat dan kapasitasnya masing-masing.

Etika ekonomi dan bisnis dimaksudkan agar prinsip dan perilaku ekonomi dan bisnis baik oleh perseorangan, institusi, maupun pengambil keputusan dalam bidang ekonomi dapat melahirkan kondisi dan realitas ekonomi yang bercirikan berkeadilan dan ekonomi yang berpihak kepada rakyat kecil melalui kebijakan secara berkesinambungan. Etika ini mencegah terjadinya praktek-praktek dan perilaku-perilaku yang menghalalkan segala cara dalam memperoleh keuntungan.

Dasar hukum dari mencoretcoret rumah ini tidak terdapat didalam aturan perundang-undangan yang berlaku. Bentuk mencoret-coret rumah ini dilakukan dengan menulis didinding depan rumah dengan tulisan "RUMAH INI DIDALAM PENGAWASAN BANK" atau "RUMAH INI DISITA OLEH BANK" dengan cat yang warnanya mencolok sehingga menimbulkan kesan malu bagi pemilik rumah. Bentuk lain coret-mencoret rumah ini adalah dengan membuat plang di rumah tersebut dengan tulisantulisan seperti yang tertera di atas. Kedudukan bank (kreditur) dan nasabah (debitur) adalah sederajat di dalam perjanjian utang piutang, namun dari segi ekonomi dan sosial kedudukan bank lebih tinggi daripada nasabah karena bank mempunyai fasilitas yang dimanfaatkan oleh nasabah. 
Dengan lahirnya UndangUndang Nomor 4 Tahun 1996 tentang Hak Tanggungan memberikan kepastian hukum bagi bank sebagai kreditur. Kedudukan bank sebagai pemegang hak tanggungan memiliki kedudukan yang lebih tinggi dibandingkan dengan kreditur-kreditur lainnya (kreditur konkurent).

Sebagai kreditur preferent pemegang hak tanggungan berhak untuk didahulukan pembayaran piutangnya dari hasil penjualan barang yang dibebani hak tanggungan. Selain itu meskipun rumah yang dijadikan obyek jaminan hak tanggungan dipindahtangankan oleh pemiliknya kepada orang lain maka pemindahan hak milik tersebut tidak menghapuskan hak tanggungan. Hak tanggungan mudah dan pasti pelaksanaan eksekusinya sebab sertifikat Hak Tanggungan memiliki kekuatan eksekutorial sama dengan putusan pengadilan (Prabowo, 2019).

Oleh sebab itu dengan dilindunginya hak-hak bank selaku kreditur oleh Undang-Undang Hak Tanggungan maka proses coretmencoret rumah harus di hilangkan karena tidak sesuai dengan asas kekeluargaan sebagaimana terdapat didalam UUD 1945 Pasal 33 ayat (1) yang berbunyi Perekonomian disusun sebagai usaha bersama berdasar atas asas kekeluargaan.

Azas kekeluargaan adalah pedoman nasional yang telah ditetapkan didalam Undang-Undang Dasar 1945 untuk mengatur perekonomian menuju masyarakat yang adil dan makmur berdasarkan Pancasila. Semangat ekonomi yang berazaskan kekeluargaan adalah semangat perekonomian yang saling tolong menolong. Puspitasari et al., (2018) dalam penelitiannya menyatakan apabila ditinjau dari perekonomian kekeluargaan hubungan antara debitur dengan kreditur dalam kredit perumahan bukan hanya sebatas kontraktual semata tetapi ada hubungan saling tolong-menolong dalam lingkup sebuah keluarga. Konsep bisnis kekeluargaan tidak menomor satukan keuntungan. Bisnis yang baik (good business) bukan saja bisnis yang menguntungkan namun bisnis yang baik adalah bisnis yang baik secara moral.

Penyelesaian sengketa kredit perumahan yang bermasalah dengan cara mencoret-coret rumah tidak menciptakan perasaan kekeluargaan karena tidak mencerminkan adanya rasa senasib sepenanggungan antara debitur dan kreditur. Dalam azas kekerluargaan debitur dan kreditur adalah satu keluarga, sekali orang sudah menjadi keluarga tidak mungkin ia membuka aib keluarganya untuk di umumkan kepada masyarakat luas.

Sistim ekonomi Pancasila mengandung nilai kekeluargaan. Nilai kekeluargaan tersebut adalah jati diri budaya bangsa. Semangat kekeluargaan itu tidak bisa dipisahkan dari akar budaya dan nilai-nilai religius yang hidup dalam masyarakat. Dengan landasan berfikir demikian, perekonomian hendak dibangun dalam suasana lingkungan kehidupan simbiosis-mutualisme, yang saling mendukung dan tidak saling menegasikan.

Salah satu pertimbangan lahirnya Undang-Undang 10 Tahun 1998 tentang Perbankan adalah untuk melakukan pembangunan yang berkesinambungan dalam rangka mewujudkan masyarakat Indonesia yang adil dan makmur berdasarkan Pancasila dan Undang-Undang Dasar 1945. Ini tertulis jelas didalam konsideran huruf a. Maka tidak ada alasan bagi lembaga perbankan untuk tidak menerapkan skema kekeluargaan 
didalam penyelesaian kredit perumahan yang bermasalah (Sutanti, 2017).

Tujuan dari ekonomi Pancasila adalah memuliakan manusia. Manusia dilihat bukan hanya dari sisi materil namun di lihat juga dalam sisi sosial. Prinsip berbagi rasa, untung sama didapat dan rugi sama dibagi sudah menjadi tatanan luhur Bangsa Indonesia. Hal ini tergambar dari peribahasa "berat sama di pikul, ringan sama di jinjing, ke bukit sama mendaki ke lurah sama menurun".

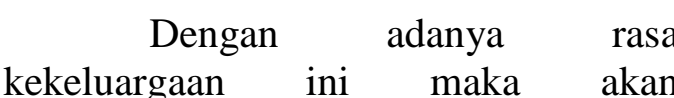
meningkatkan rasa solidaritas yang kuat di bidang ekonomi di tengah-tengah masyarakat, adanya saling bantu membantu dan bahu membahu dalam kegiatan perekonomian melahirkan kesejahteraan yang merata bagi seluruh rakyat Indonesia sehingga mengantarkan negara Indonesia menjadi negara yang makmur.

\section{PENUTUP}

\section{Kesimpulan}

Skema penyelesaian kredit perumahan yang bermasalah dengan cara mencoret-coret rumah tidak sesuai dengan azas kekeluargaan dan keadilan. Efek dari coret-mencoret rumah tersebut selain rugi dalam materil juga debitur mengalami kerugian secara sosial karena tulisan di dinding rumah bisa dilihat banyak orang serta menimbulkan citra negatif kepada debitur. Dalam sistim ekonomi Pancasila yang bercorak kekeluargaan kegiatan ekonomi bukan hanya dilihat dari sisi materil saja, namun ada sisi lain berupa saling tolong menolong dan saling menghargai.

\section{Saran}

Kedepannya skema penyelesaian kredit perumahan yang bermasalah dengan cara coret-mencoret dinding rumah debitur bisa hilangkan serta diharapkan kepada lembaga-lembaga terkait yang melakukan pengawasan terhadap lembaga keuangan salah satunya Otoritas Jasa Keuangan (OJK) bisa bertindak aktif untuk menghilangkan praktek-praktek tersebut.

\section{DAFTAR PUSTAKA}

Ellsya, A., \& Kashadi, S. M. B. (2016). Penyelesaian Kredit Macet Kendaraan Bermotor dengan Jaminan Fidusia (Studi Kasus pada PT. Nusa Surya Ciptadana Semarang). Diponegoro Law Journal, 5(2), 1-14.

Muhtar, L. (2017). Penyelesaian Kredit Macet Pada Koperasi Serba Usaha Surya Kabupaten Barru Dikaitkan Dengan Pasal 1243 KUHPerdata (Doctoral dissertation, UIN Sunan Gunung Djati Bandung).

Purwanto, R. H. (2016). Perjanjian Kredit Pada Koperasi Wanita (Kopwan)" Insan Sejahtera" Oleh Debitur Yang Wanprestasi. Jurnal Pro Hukum: Jurnal Penelitian Bidang Hukum Universitas Gresik, 5(1).

Puspitasari, D., Darsono, S. H., \& Hum, M. (2018). Pelaksanaan Perjanjian Kredit Koperasi Pegawai Negeri Di Koperasi Guru Bayat Klaten (Doctoral dissertation, Universitas Muhammadiyah Surakarta).

Prabowo, S. (2019). Penyelesaian Kredit Macet Dalam Perjanjian Kredit Pemilikan Rumah (KPR). Diponegoro Private Law Review, 4(1).

Rahmawan, F. R., Inayah, S. H., \& Hum, M. (2017). Implementasi Asas Kekeluargaan Dalam Penanganan Pinjaman Bermasalah Di Koperasi Pegawai Republik Indonesia 
Berdasarkan Undang-Undang No. 25 Tahun 1992 Tentang Perkoperasian (Studi Kasus Di Koperasi Manunggaling Karso Yuwana/Kpri. Makarya, Kec. Jebres, Kota Surakarta) (Doctoral dissertation, Universitas Muhammadiyah Surakarta).

Rusmawati, D. E. (2015). Tinjauan Yuridis Penyelamatan Dan Penyelesaian Kredit Macet (Studi Pada Koperasi Kredit Mekar Sai Bandar Lampung). Fiat Justisia, 6(1).

Suarjaya, I. N., Cipta, W., \& Zukhri, A. (2017). Analisis Penyelesaian Kredit Macet Pada Koperasi Pasar Srinadi Klungkung. Jurnal Pendidikan Ekonomi Undiksha, 5(1).

Sutanti, A. (2017). Perlindungan Hukum Bagi Konsumen Pemberi Anggunan Dalam Transaksi Kredit Pada Lembaga Keuangan Bank (Kajian Terhadap Pembebanan Hak Tanggungan) Pada PD BKK Susukan Kabupaten Semarang. Jurnal Akta, 4(4), 677-688. 